and "National Guard"of the last Ukrainian Hetman (April-December 1918)]. - Kul tura narodov Prichernomor ia. - Culture of the black sea peoples. 7, 135-144 [in Ukrainian].

Tymoshchuk O.V. (1999b). Viys 'kovo-kozats 'ka organizatsiya Ukrains 'koyi derzhavy 1918 r. [Military-Cossack organization of the Ukrainian state in 1918]. - Visnyk Zaporiz 'kogo yurydychnogo instytutu MVS Ukrainy. Bulletin of the Zaporozhye Law Institute of the Ministry of internal affairs of Ukraine. 3, 160-169 [in Ukrainian].

Tymoshchuk O.V. (2000). Okhoronnyy aparat Ukrains koy derzhavy (kviten '-gruden` 1918 r.): istoriko-pravove doslidzhrnnia [Security apparatus of the Ukrainian state (April - December 1918): historical and legal investigation]. Extended summary of the doctoral dissertation. Odessa [in Ukrainian].

Tkachuk P.P. (2019). Viys`kova reformy get mana Pavla
Skoropads`kogo u konteksti derzhavotvorchykh protsessiv v Ukraini (kviten '-gruden` 1918 r.) [Military reforms of Hetman Pavlo Skoropadsky in the context of state processes in Ukraine (April - December 1918)]. Viys kovo-naukovyy visnyk. - Military scientific bulletin. 31, 112-123 [in Ukrainian].

Udovychenko O. (1995). Ukraina u borot'bi za derzhavnict'. Istoriya organizatsii boyovykh duy Ukrains 'kykh Zbroynykh Syl 1917-1921 rr. [Ukraine in the struggle for statehood. History of the organization of military operations of the Ukrainian Armed Forces in 19171921]. Kiyv: Ukraina [in Ukrainian].

Pyrig R.Ya. (Eds.). (2015). Ukrayns`ka Derzhava (kviten '-gruden' 1918 roku). [Ukrainian state (April December 1918)]. Dokumenty i materialy. V. 2 (Vol. 12, 3 part.). Kiyv: Tempora [in Ukrainian].

УДК 346.1

DOI 10.34142/2313-2345.2020.58.06

Олійник Юлія Олександрівна кандидат педагогічних наук, дочент кафедри економічної теорії, фінансів і обліку Харківського начіонального педагогічного університету імені Г.С. Сковороди https://orcid.org/0000-0002-2647-9166

Мельникова Ольга Володимирівна кандидат педагогічних наук, доцент, дочент кафедри економічної теорії, фінансів і обліку Харківського національного педагогічного університету імені Г.С. Сковороди https://orcid.org/0000-0001-8832-5763

\title{
ІСТОРІЯ РОЗВИТКУ ПРАВА НА ПІДПРИЕМНИЦЬКУ ДІЯЛЬНІСТЬ В СУЧАСНІЙ УКРАЇНІ
}

У статті досліджується історія розвитку права на підприємництво та підприємницьку діяльність в сучасній Украӥні з 1991 р. Автори аналізують нормативні джерела по закріпленню і регулювання підприємницької діяльності. Пропонується авторське бачення розвитку підприємницької діяльності в Україні та даються висновки і рекомендації щзодо подальшого розвитку изього права в Україні.

Ключові слова: право на підприємнищьку діяльність,покоління прав людини, підприємництво, підприємецьь, свобода,конституційна свобода, нормативні джерел, омбудсман.

The article analyzed a history of development of entrepreneurship and the right on entrepreneurial activity in modern Ukraine since 1991.

Economic views of the English economist of the XVII - XVIII centuries. R. Cantillon convinces us that for the first time the concepts of «entrepreneur» and "entrepreneurship» were introduced into economic theory by him. He considered the essence of entrepreneurship as an economic activity aimed at making a profit, and considered the economic role of the entrepreneur "the main driver of the economy"

Later, along with the victory of the French Revolution and the adoption of the Universal Declaration of Human Rights in France, for the first time the human right to engage in labor, trade, and contract work was mentioned in law. And although historians and lawyers attribute the right to entrepreneurial activity to the second generation of human rights, as well as other economic rights and which was finally formed in the first half of XX century. It can be emphasized that this right began to take shape much earlier.Rights and freedoms in the Soviet Union, even if not observed, at least formally proclaimed, in the case of the right to entrepreneurial activity, the state took a clear negative position.

In independent Ukraine, the constitutional freedom of a person to do business was further developed after the adoption by the Verkhovna Rada of Ukraine of the "Declaration of State Sovereignty of Ukraine» of 
July 16, 1990 and the "Act of Independence in Ukraine» of August 24, 1991. We think that, the right to entrepreneurial activity is recognized by the Constitution and laws of Ukraine opportunities for certain behavior of man and citizen in the field of production in order to make a profit.

The authors examine normative sources on the consolidation and regulation of the entrepreneurial activity. To propagate the author's development of entrepreneurial activity in Ukraine and to give recommendations for the development of this law in Ukraine.

Key words: right on entrepreneurial activity, generation of human rights, entrepreneurship, a entrepreneur, freedom, constitutional freedom, normative sources, ombudsman.

Постановка проблеми дослідження. Досліджуючи проблему розвитку права на підприємницьку діяльність в Україні, важливо проаналізувати появу самих термінів «підприємництво» і «підприємець». Економічні погляди англійського економіста кінця XVII - початку XVIII ст. Р. Кантільона переконують нас у тому, що вперше поняття «підприємець» та «підприємництво» в економічну теорію було введено саме ним. Він розглядав суть підприємництва як господарську діяльність, що мала на меті одержання прибутку, а господарську роль підприємця вважав «головним рушієм економіки» [3]. Пізніше разом 3 перемогою Великої Французької революції і прийняття Загальної декларації прав людини у Франції вперше законодавчо згадується про право людини на зайняття працею, торгівлею, а також працею за договором (ст.17-18) [4]. I хоча історики і юристи відносять право на підприємницьку діяльність до другого покоління прав людини, як і інші економічні права і яке було остаточно сформовано у першій половині XX ст. [21, Р. 6851]. Можна наголосити, що це право почало формуватись значно раніше.

Аналіз актуальних досліджень 3 iсторії розвитку права на підприємницьку діяльність свідчить, що ця проблема $\epsilon$ предметом розгляду науковців. Так, деякі аспекти цього питання висвітлилися у працях Г.І.Борисова, Н.І.Карпачової, А.Н.Нiфанова, А.Ю.Олійника, М.М.Олійника, В.Ф.Погорілка, С.В.Різника, О.П.Савчука, Н.О.Саніахметової, П.М.Рабіновича, Ю.М.Фролова, Pablo Chang Ibarra та ін.

Метою статті $\epsilon$ історичне формування права на підприємницьку діяльність в сучасній незалежній Україні з 1991 р. по сучасний час. Також автори дають пропозиції висновків і рекомендацій щодо подальшого розвитку конституційної свободи фізичної особи на підприємницьку діяльність.
Виклад основного матеріалу. У незалежній Україні конституційна свобода особи на підприємницьку діяльність отримала подальший розвиток після прийняття Верховною Радою України «Декларації про державний суверенітет України» від 16 липня 1990 р. та «Акта проголошення незалежності України» від 24 серпня 1991 р. [16, c.53]

Для сучасної України підприємництво - явище відносно нове. Легальний відлік історії сучасного українського підприємництва починається з 7 лютого 1991 р. 3 прийняттям законів України «Про власність» [7] та «Про підприємництво» [11]. Логічним завершенням розвитку профільного законодавства у сфері підприємницької діяльності став Господарський Кодекс України, прийнятий 16 січня 2003 р. [1], який передусім має на меті забезпечення зростання ділової активності суб'єктів господарювання, розвитку підприємництва і на цій основі підвищення ефективності суспільного виробництва, його соціальної спрямованості відповідно до вимог Конституції України, утвердження суспільного господарського порядку в економічній системі України, сприяння гармонізації іiї з іншими економічними системами.

Хоча прав і свобод у Радянському Союзі й не дотримувалися, та формально їх проголошували. Проте щодо права на підприємницьку діяльність держава займала однозначну негативну позицію [17, с. 7]. Право громадян на підприємницьку діяльність та реалізація даного права забезпечують виконання ряду важливих соціальних функцій: 1) підприємництво громадян - один 3 найважливіших каналів докорінної трансформації нашого суспільства, його соціально-економічного ладу на началах ринкової економіки, розвитку господарської ініціативи самих членів суспільства; 2) воно є могутнім важелем формування громадянсь- 
кого суспільства; 3) підприємництво сприяє підвищенню трудової зайнятості населення, що набуває особливе значення в умовах переходу до ринку та звільнення значної кількості осіб з сфери виробництва, заснованого на державній власності; 4) сприяє більш повному задоволенню потреб громадян у товарах масового попиту та послугах; 5) призводить до підвищення матеріального добробуту осіб, які займаються даною діяльністю, розвитку матеріального потенціалу суспільства [18, с. 14].

Однак закріплення на конституційному рівні права на підприємницьку діяльність об'єктивно викликає не лише необхідність визначення самого поняття даного права у нормативних актах, спрямованих на регулювання підприємницької діяльності (Цивільному, Господарському, Торговому (за умовою розробки й прийняття) кодекcax), a й ставить перед правовою наукою завдання всебічного наукового дослідження сутності, змісту та інших характеристик даного права [19, с. 73]. Перед тим як перейти до суб'єктно-об'єктного аналізу права на підприємницьку діяльність, спробуємо дати визначення даного права. Так, відповідно до Закону України «Про підприємництво» підприємницька діяльність визначалась як систематична на власний ризик діяльність по виробництву продукції, виконанню робіт, наданню послуг та заняття торгівлею 3 метою одержання прибутку, а підприємництво - як самостійна ініціатива особи яка вирішила займатися цією діяльністю [11]. У відповідності з чинним Господарським кодексом України, підприємництво (господарська комерційна діяльність) - це самостійна, ініціативна, систематична, на власний ризик господарська діяльність, що здійснюється суб'єктами господарювання (підприємцями) з метою досягнення економічних і соціальних результатів та одержання прибутку (ст. 42) [1]. На нашу думку, за своєю суттю право на підприємницьку діяльність - це визнані Конституцією та законами України можливості певної поведінки людини і громадянина в сфері виробництва 3 метою одержання прибутку. За своїм змістом право людини і громадянина на підприємницьку діяльність - це певні матеріальні блага в сфері виробництва та права на ці блага, а саме: право на їхній обмін, розподіл, володіння, користування, розпорядження, одержання прибутку. В контексті нашого дослідження ми будемо аналізувати суб'єктне коло виключно фізичних осіб - носіїв конституційного права на підприємницьку діяльність. Згідно ст. 2 3акону України «Про підприємництво» суб'єктами підприємницької діяльності (підприємцями) визначалися громадяни України, інших держав, особи без громадянства, не обмежені законом у правоздатності або дієздатності [11].

Чинний Господарський кодекс України встановлює, що суб'єктами господарювання визнаються учасники господарських відносин, які здійснюють господарську діяльність, реалізуючи господарську компетенцію (сукупність господарських прав та обов'язків), мають відокремлене майно i несуть відповідальність за своїми зобов'язаннями в межах цього майна, крім випадків, передбачених законодавством (частина перша ст. 55), серед яких окремо виділяються громадяни України, іноземці та особи без громадянства, які здійснюють господарську діяльність та зареєстровані відповідно до закону як підприємці [1]. Щодо фізичних осіб - суб'єктів підприємницької діяльності, то аналіз Глави 4 «Господарська комерційна діяльність (підприємництво)» Господарського кодексу України дозволяє виокремити лише громадян України (частина третя ст. 45) та іноземних громадян (ст. 50). Ключовою категорією для класифікації суб'єктів права людини і громадянина на підприємницьку діяльність є цивільно-правові інститути правоздатності та дієздатності. Згідно зі ст. 25 Цивільного кодексу України [20] під правоздатністю розуміється здатність фізичної особи мати цивільні права та обов'язки. Виникає вона в момент народження людини і припиняється зі смертю. У випадках, встановлених законом, здатність мати окремі цивільні права та обов'язки може пов'язуватися 3 досягненням фізичною особою відповідного віку. Дієздатність фізичної особи, як випливає із ст. 30 Цивільного кодексу України, це здатність громадян своїми діями набувати цивільних прав і самостійно їх здійснювати, а також здатність своїми діями створювати 
для себе цивільні обов'язки, самостійно їх. Дієздатність $є$ однією з головних ознак, яка має значення для набуття особою статусу індивідуального підприємця. Ст. 127 Конституції України забороняє займатися підприємницькою діяльністю суддям. Раніше Законами України «Про підприємництво» [11], а нині Господарським кодексом України [1], а також законами «Про державну службу» [8], «Про альтернативну (невійськову) службу» [5], «Про статус депутатів місцевих рад» [12] та деякими іншими встановлено, що не вправі займатися підприємницькою діяльністю безпосередньо, отримувати від цього прибуток, якщо інше не передбачено законом такі категорії осіб:

- народні депутати України;

- депутати Верховної Ради АРК;

- депутати місцевих рад, які обрані на посаду секретаря сільської, селищної, міської ради, голови районної, обласної, районної в місті ради;

- сільські, селищні, міські голови і голови районних, обласних рад;

- службовці органів законодавчої та виконавчої влади, судді, прокурори і слідчі прокуратури, інші державні службовці;

- військовослужбовці, а також громадяни, які проходять альтернативну службу.

Господарський процесуальний кодекс України дозволяє підприємцям-громадянам звертатися до господарського суду за захистом своїх порушених або оспорюваних прав i охоронюваних законом інтересів [2]. Окрім зазначених форм впливу на розвиток підприємництва, держава забезпечує захист конкуренції, не допускає зловживання монопольним становищем, неправомірне обмеження конкуренції та недобросовісної конкуренції тощо. Так, з метою забезпечення захисту конкуренції (тобто змагальності підприємців, коли їх самостійні дії обмежують можливості кожного з них впливати на загальні умови реалізації товарів на ринку і стимулюють виробництво тих товарів, яких потребують споживачі), та недопущення зловживання монопольним становищем на ринку, відповідно до законів України «Про захист економічної конкуренції» [10], «Про Антимонопольний комітет України» [6], «Про захист від недобросовісної конкуренції» [9] та деяких інших, дер- жава визначає перелік порушень антимонопольного законодавства. Вони поділяються на чотири групи:

1) зловживання монопольним становищем на ринку;

2) неправомірні угоди між підприємцями (угоди про розподіл ринків з метою їх монополізації, про обмеження доступу на ринок інших підприємців тощо);

3)дискримінація підприємців органами влади і управління (встановлення обмежень на здійснення окремих видів діяльності, на виробництво певних товарів 3 метою обмеження конкуренції, встановлення заборони на реалізацію товарів $з$ одного регіону в інший, обмеження прав підприємців щодо придбання та реалізації товарів тощо);

4) недобросовісна конкуренція, а саме: неправомірне використання ділової репутації підприємця; створення перешкод підприємцям у процесі конкуренції та досягнення неправомірних переваг у конкуренції; неправомірне збирання, розголошення та використання комерційної таємниці; замовлення, виготовлення, розміщення чи поширення реклами, яка не відповідає вимогам чинного законодавства і може завдати шкоди споживачам або державі. 3 метою захисту чесної підприємницької діяльності, боротьби 3 порушеннями антимонопольного законодавства статтями 1643, 1661-1664 Кодексу України про адміністративні правопорушення встановлена адміністративна відповідальність службових осіб та підприємців за такі діяння, як недобросовісна конкуренція; зловживання монопольним становищем на ринку; неправомірні угоди між підприємцями; дискримінація підприємців органами влади і управління; порушення порядку подання інформації та виконання рішень Антимонопольного комітету України та його територіальних відділень [14]. Кримінальним кодексом України [15] передбачено кримінальну відповідальність за такі злочини, як крадіжка (ст.185); вимагання (ст. 189); шахрайство (ст. 190); порушення порядку зайняття господарською та банківською діяльністю (ст. 202); зайняття забороненими видами господарської діяльності (ст. 203); фіктивне підприємництво (ст. 205); протидія законній господарській діяльності (ст. 206); ухилення від сплати 
податків, зборів, інших обов'язкових платежів (ст. 212); фіктивне банкрутство (ст. 218); доведення до банкрутства (ст. 219); шахрайство 3 фінансовими ресурсами (ст. 222); порушення порядку випуску (емісії) та обігу цінних паперів (ст. 223); змова про зміну чи фіксування цін або примушування до їх зміни чи фіксування (ст. 228); незаконне використання товарного знаку (ст. 229); порушення антимонопольного законодавства (ст. 230); незаконне збирання 3 метою використання або використання відомостей, що становлять комерційну таємницю (ст. 231); розголошення комерційної таємниці (ст. 232) тощо.

Насамкінець окреслимо коло найболючіших проблем у сфері захисту права людини і громадянина на підприємництво в Україні. Аналіз реального стану справ у сфері захисту прав підприємців показує, що чинне законодавство явно недостатньо сприяє їх захисту. За свідченням першого омбудсмана України Н.І.Карпачової, одним 3 найтиповіших порушень прав громадян на підприємницьку діяльність $є$ надмірне втручання органів державної влади в діяльність суб' єктів господарювання. Особи, які займаються підприємницькою діяльністю, постійно стикаються із проблемами, які виникають між ними і посадовими особами владних структур [13, с.344-345]. Можна окреслити коло найболючіших проблем у сфері захисту права людини і громадянина на підприємництво в Україні. Аналіз реального стану справ у сфері захисту прав підприємців показує, що чинне законодавство явно недостатньо сприяє їх захисту.

Болючою проблемою для розвитку підприємництва $є$ податкове навантаження. Його зниження сприяло б усуненню передумов, через які підприємці змушені ховатися від податку, а податківцям - підстав постійно тримати під контролем підприємства i, крім стягування податків, нараховувати ще й величезні штрафи.

За свідченням першого омбудсмана України Н. І. Карпачової, одним із найтиповіших порушень прав громадян на підприємницьку діяльність $є$ надмірне втручання органів державної влади в діяльність суб'єктів господарювання. Особи, які займаються підприємницькою діяльністю, постійно стикаються із проблемами, які виникають між ними і посадовими особами владних структур [13, с.344-345].

Висновки. Усе це, безумовно, вимагає кардинального реформування системи, яке виключало б втручання органів державної влади і органів місцевого самоврядування та їх посадових осіб у діяльність суб'єктів господарювання, усунення правових перешкод у здійсненні підприємницької діяльності, забезпечення гарантованого Конституцією України права на свободу підприємництва.

\section{ЛIТЕРАТУРА}

1. Господарський кодекс України від 16 січня 2003 р. // ВBP. 2003. № 18. Ст. 144.

2. Господарський процесуальний кодекс України від 6 листопада 1991 р. // ВВР. 1992. №6. Ст. 56.

3. Економічні погляди Ричарда Кантільйона. URL.: http.://pidruchniki.com/1334020360183/ekonomika/e konomichni_poglyadi_richarda_kantilyona (дата звернення: 15.01.2020).

4. Всеобщая декларация прав человека / Голос України від 10.12.2008. № 236.

5. Закон України «Про альтернативну (невійськову) службу» від 12 грудня 1991 р. // Голос України від 21.03.1992.

6. Закон України «Про Антимонопольний комітет України» від 26 листопада 1993 р. // Голос України від 21.12.1993.

7. Закон України «Про власність» від 7 лютого 1991 p. ( не діючий) // Голос України від 24.04.1991.

8. Закон України «Про державну службу» від 16 грудня 1993 р. // Голос України від 05.01.1994.

9. Закон України «Про захист від недобросовісної конкуренції» від 7 червня 1996 р. // ВВР. 1996. № 36. Ст. 164.

10.Закон України «Про захист економічної конкуренції» від 11 січня 2001 р. // Урядовий кур'єр від 21.03.2001. № 50 .

11. Закон України від 7 лютого 1991 р. «Про підприємництво» (не діючий) // ВВР УРСР. 1991. № 14 Ст. 68

12. Закон України «Про статус депутатів місцевих рад» від 11 липня 2002 р. // Голос України. 2002. 7 серп.

13. Карпачова H.I. Стан дотримання та захисту прав i свобод людини в Україні: Перша щорічна доповідь Уповноваженого Верховної Ради України 3 прав людини. К.: Книжкова друкарня Наукової книги, 2000. С.344-355.

14. Кодекс України про адміністративні правопорушення від 7 грудня 1984 р. // ВВР УРСР. 1984. № 51. Ст. 1122 .

15. Кримінальний Кодекс України від 5 квітня 2001 р. // Голос України від 19.06.2001. № 107. 
16. Олійник А.Ю. Виникнення і розвиток конституційної свободи особи на підприємницьку діяльність. Право і суспільство. 2018. Вип. 3. С. 49-55.

17. Різник С.В. Забезпечення державою конституційного права людини і громадянина на підприємницьку діяльність: автореф дис. канд. юрид. наук: 12.00.02 / С.В. Різник. Ужгород, 2012. 16 с.

18. Савчук А.П. Роль органов внутренних дел в укреплении законности и охране прав граждан в сфере предпринимательства: автореф. дис. канд. юрид. наук: 12.00 .03 / А.П. Савчук. К., 1992. 18 с.
19. Саниахметова Н. Конституционное право на предпринимательскую деятельность и его защита. Юридический вестник. 1996. №1. С. 73-74.

20. Цивільний кодекс України від 16 січня 2003 р. // Голос України від 12.03.2003 - № 45.

21. Gennadiy I Borisov, Nikolay N Oleinik, Anatoliy N. Nifanov Alexander N. Oleinik, Pablo Chang Ibarra, Vladimir G. Ostapiuk Interaction of the State and the Individual in the Context of the Development of Generations of Human Rights. The Social Sciences. 2016. Vol. 29. P. 6849-6853.
1. Hospodarskyi kodeks Ukrainy vid 16 sichnia $2003 \mathrm{r}$. // VVR. 2003. № 18. St. 144 [in Ukrainian].

2. Hospodarskyi protsesualnyi kodeks Ukrainy vid 6 lystopada 1991 r. // VVR 1992. №6. St. 56 [in Ukrainian].

3. Ekonomichni pohliady Rycharda Kantiliona. URL.: http.://pidruchniki.com/1334020360183/ekonomika/e konomichni_poglyadi_richarda_kantilyona (data zvernennya: 17.01.2020) [in Ukrainian].

4. Vseobschaya deklaratsiya prav cheloveka (2008). Holos Ukrainy, 236 [in Russian].

5. Zakon Ukrainy «Pro alternatyvnu (neviiskovu) sluzhbu» vid 12 hrudnia 1991 r. // Holos Ukrainy vid 21.03.1992 [in Ukrainian].

6. Zakon Ukrainy «Pro Antymonopolnyi komitet Ukrainy» vid 26 lystopada 1993 r. // Holos Ukrainy vid 21.12.1993 [in Ukrainian].

7. Zakon Ukrainy «Pro vlasnist» vid 7 liutoho $1991 \mathrm{r}$. (ne diiuchyi) // Holos Ukrainy vid 24.04.1991 [in Ukrainian].

8. Zakon Ukrainy «Pro derzhavnu sluzhbu» vid 16 hrudnia 1993 r. // Holos Ukrainy vid 05.01.1994 [in Ukrainian].

9. Zakon Ukrainy «Pro zakhyst vid nedobrosovisnoi konkurentsii» vid 7 chervnia 1996 r. // VVR. 1996. № 36. St. 164 [in Ukrainian].

10. Zakon Ukrainy «Pro zakhyst ekonomichnoi konkurentsii» vid 11 sichnia 2001 r. // Uriadovyi kurier vid 21.03.2001. № 50 [in Ukrainian].

11. Zakon Ukrainy vid 7 liutoho 1991 r. «Pro pidpryiemnytstvo» (ne diiuchyi) // VVR URSR. 1991. № 14. st. 168 [in Ukrainian].

12. Zakon Ukrainy «Pro status deputativ mistsevykh rad» vid 11 lypnia 2002 r. // Holos Ukrainy. 2002. 7 serp [in Ukrainian].
13. Karpachova N.I. Stan dotrymannia ta zakhystu prav i svobod liudyny v Ukraini: Persha shchorichna dopovid Upovnovazhenoho Verkhovnoi Rady Ukrainy z prav liudyny. K.: Knyzhkova drukarnia Naukovoi knyhy, 2000. S.344-355 [in Ukrainian].

14. Kodeks Ukrainy pro administratyvni pravoporushennia vid 7 hrudnia 1984 r. // VVR URSR. 1984. № 51. St. 1122 [in Ukrainian].

15. Kryminalnyi Kodeks Ukrainy vid 5 kvitnia 2001 r. // Holos Ukrainy vid 19.06.2001 № 107 [in Ukrainian].

16. Oliinyk A.Iu. Vynyknennia i rozvytok konstytutsiinoi svobody osoby na pidpryiemnytsku diialnist. Pravo i suspilstvo. 2018. Vyp. 3. S. 49-55 [in Ukrainian].

17. Riznyk S.V. Zabezpechennia derzhavoiu konstytutsiinoho prava liudyny i hromadianyna na pidpryiemnytsku diialnist: avtoref dys. kand. yuryd. nauk: 12.00.02 / S.V. Riznyk. Uzhhorod, 2012. 16 s. [in Ukrainian].

18. Savchuk A.P. Rol organov vnutrennih del v ukreplenii zakonnosti i ohrane prav grazhdan v sfere predprinimatelstva: avtoref. dis. kand. yurid. nauk: 12.00.03 / A.P. Savchuk. K., 1992. 18 c. [in Russian].

19. Saniahmetova N. Konstitutsionnoe pravo na predprinimatelskuyu deyatelnost i ego zaschita. Yuridicheskiy vestnik. 1996. \#1. S. 73-74 [in Russian].

20. Tsyvilnyi kodeks Ukrainy vid 16 sichnia 2003 r. // Holos Ukrainy vid 12.03.2003. № 45 [in Ukrainian].

21. Gennadiy I Borisov, Nikolay N Oleinik, Anatoliy N. Nifanov Alexander N. Oleinik, Pablo Chang Ibarra, Vladimir G. Ostapiuk Interaction of the State and the Individual in the Context of the Development of Generations of Human Rights. The Social Sciences. 2016. Vol. 29. P. 6849-6853 [in English]. 